\title{
THE CONTEXT OF LEARNING ENGLISH AS A FOREIGN LANGUAGE (AL2LC SCALE)
}

Jelena V. Grubor, State University of Novi Pazar, Serbia, bram.english@yahoo.co.uk

\begin{abstract}
The context of $\mathrm{L} 2$ learning $\left(\mathrm{L}_{2} \mathrm{LC}\right)$ is the most immediate learning environment for L2 learners, hence potentially influencing their L2 attitudes and linguistic behaviour. In this paper, we focused on an affective variable (students' attitudes), and social (the classroom as a community of practice/CoP), but also cultural indirectly (students' integration into their $\mathrm{CoP}$ ). The main aim of the study was to explore the attitudes of two age and educational profile groups to the $\mathrm{L}_{2} \mathrm{LC}$, and subsidiary to determine whether their evaluation of the $\mathrm{L}_{2} \mathrm{LC}$ is connected with the extent to which they are exposed to the L2 through its use as the language of instruction $\left(\mathrm{L}_{2} \mathrm{LoI}\right)$, and the age when they started learning the L2. The main administered instrument was the $\mathrm{AL}_{2} \mathrm{LC}$ scale, which showed good psychometric properties, and the gathered quantitative data were analysed in IBM SPSS 21. In a nutshell, the results show that the $\mathrm{L}_{2} \mathrm{LC}$ is one composite factor, closely connected with the frequency of use $\mathrm{L}_{2} \mathrm{LoI}$, which gives rise to its actual employment in L2 classes. Secondary school students evaluated their overall $\mathrm{L}_{2} \mathrm{LC}$ better, and significant differences were found between the age and educational profile groups on individual components. In conclusion, further investigations are needed in order to analyse the $\mathrm{L}_{2} \mathrm{LC}$ in more detail, but within a broader concept of the L2 learning environment, including other sources of input learners are exposed to, as well as their relation to students' L2 learning attitudes, and potentially achievement.
\end{abstract}

Keywords: $\mathrm{AL}_{2} \mathrm{LC}$ scale, communities of practice, the context of $\mathrm{L} 2$ learning $\left(\mathrm{L}_{2} \mathrm{LC}\right), \mathrm{L} 2$ as the language of instruction $\left(\mathrm{L}_{2} \mathrm{LoI}\right), \mathrm{L} 2$ attitudes

\section{L2 learning context within SLA: Then and now}

Discovering the mechanisms underlying the acquisition of a second and foreign language (L2) has long been at the heart of Second language acquisition (SLA) studies. Consequently, the SLA literature "abounds in approaches, theories, models, laws, and principles" (Ellis, 1985 248), with no "unifying theory" so far developed. Two broad views on language learning have been particularly influential, i.e. cognitive, and 
more recently social. Put broadly and plainly, the former focuses on more general cognitive processes relative to SLA, and views language learning as a "complex cognitive skill", without the need to define an innate linguistic mechanism (McLaughlin; Mitchell, Myles, and Marsden), as Universal Grammar does for instance. The latter places social and contextual orientations at the forefront, underlining "larger social constructs, groups, histories, boundaries, and ideologies that are also discursively invoked and (re)produced in social settings" (Duff 380). Although both perspectives aim at the same goal (De Costa and Crowther 22), no consensus has yet been reached about the scope of SLA research.

What many researchers agree on, however, is the fact that learning an L2 is unlike any other kind of learning (e.g. playing a game), and it also differs from learning of any other school subject in instructional contexts (e.g. maths) (Grubor, 2015; Dörnyei; Ellis, 1990; Gardner, 2007). If we, therefore, try to make a more unified view on L2 language learning, we can state that SLA in its complexity entails the cognitive element (e.g. language aptitude), affective (e.g. attitudes to L2 and L2 learning), social (e.g. social networks and/or communities of practice), and cultural (e.g. the level of acculturation into the target and/or imagined language community). Since many people and researchers regard language learning as a "purely intellectual activity", but also "something they are passionate about because they enjoy understanding how different languages work" (Duff 379), we must consider factors that are beyond the individual's cognitive abilities in contrast to a vast body of research that has been conducted in that direction for many years behind us.

Since many authors point to the importance of the context in understanding SLA (e.g. Littlewood), the subject matter of our study will be students' evaluations of the context where they learn English in instructional settings, as an instance of the most immediate learning environment. L2 learning environment represents in general everything the learner hears or sees in an L2, and all the situations in which the learner comes into contact with the L2 (cf. Dulay, Burt, and Krashen), as well as the way they experience learning it. Furthermore, the role of participation in learning (and participation as learning) has become foregrounded in the SLA research since the 1990s (e.g. Grubor, 2020a; Zappa-Hollman and Duff). The variable that has been regarded as central to L2 learning is the input that learners receive and/or are exposed to (Miličević Petrović and Grubor, 183). This is common ground for a wide range of authors belonging to different perspectives since they agree that no language can be acquired without a sufficient amount of input 
(Gass) ${ }^{7}$. Input, can be further classified as in- and out-of-class input, and can also comprise the $L 2$ as the language of instruction (cf. Grubor, 2018), since any sample of language serves that function. This variable might play an important role in bringing an $\mathrm{L} 2$ closer to its learners and forming more positive attitudes to L2 learning, as some studies suggest (cf. Grubor, 2020a). Similarly, the more frequent the use of $L 2$, the more exposed the learner gets to the target language, which may be the reason why using the $L 2$ only (i.e. as the language of instruction, and in any kind of class members' correspondence with their teacher and peers in class, and preferably out of class with their teacher) seems to be regaining its former glory. In sum, variables such as input, L2 as the language of instruction, and learners' most immediate learning environment are potential contributors to better achievement in L2, as well as the formation of attitudes (Grubor, forthcoming).

The context of learning an L2, which is our focus, has long been termed as the basic, typically clear-cut, distinction between the two learning settings, i.e. learning an L2 as a second (SLL) and foreign language (FLL). The former is usually defined as the official, societally dominant language, used in the learner's immediate social surroundings and fulfilling many important functions (e.g. a medium of instruction in education, language used in a work environment, in everyday encounters etc) when acquired by minority groups and/or immigrants. The latter normally refers to the language that is learnt in instructional/classroom settings, as a curricular requirement (e.g. Gass and Selinker 7; Saville-Troike 4; VanPatten and Benati 180). Both languages, however, refer to non-native languages (i.e. languages other than the speaker's mother tongue/L1). This division is in line with Krashen's distinction between acquisition and learning, within his Monitor Model (Krashen), whereby the former refers to the process of rule internalisation, is meaning-oriented and nonconscious, brought about by exposure to comprehensible input, while the latter pertains to the study of explicit rules of language, which is apparently rulegoverned, and hence conscious/deliberate (Richards and Schmidt 312).

Many authors, nevertheless, rightfully question or highlight the need for revisiting this distinction, either by acknowledging the existence of different types of knowledge (e.g. implicit v. explicit, declarative v. procedural, conscious metalinguistic v. underlying tacit knowledge), regardless of the L2 learning setting, or by underlining that in modern society, in times of globalisation, this distinction is becoming

\footnotetext{
${ }^{7}$ For problems of input measurement, cf. Grubor (2018); Miličević Petrović and Grubor.
} 
growingly fuzzier since foreign language learners have ample opportunities for extra-class exposure to L2 (e.g. Grubor, 2018; Butler). Furthermore, there are examples of SLL where there are speakers whose use of L2 is limited only to the educational environment, due to their social networks and/or communities of practice, and there are also instances where speakers believe they assert their identities by adhering strictly to their L1 cultural values, one of them being L1, in fear of losing their roots. In a similar vein, there are instances where FLL can be restricted only to classroom settings, but also they can be exposed to a wide range of visual and aural stimuli (e.g. the Internet, mass media, music, apps etc). Finally, even classroom settings can vary greatly in the amount and quality of input they provide for learners.

This is the reason why many researchers use the concept of context in a rather different sense, to refer to different frameworks created within a certain geographical region, where certain educational strategies and policies dictate the way teaching is carried out. Thus, Burt, for example, deals with instructed second language acquisition in East Asian contexts, and states that "sociocultural traditions, educational environments, and learning needs" all determine "the ways learners engage in and make use of language input" (324). Accordingly, the context is regarded as wider socioeducational surroundings, in which L2 learning predominantly follows certain socioculturally imposed beliefs and practices. These socioeducational contexts also impact on perceptions and attitudes to both learning and teaching (ibid.). This move comes as no surprise if we consider in addition the increasing number of scholarly papers dealing with World Englishes, and theories underpinning the claim on "shared ownership" of the English language, whereby the language belongs not only to native speakers, but rather to all people using the language with all the modifications they make to it and with all culturally-induced meanings attached to their utterances. Thus, we can come across constructs such as English as an international (auxiliary), global language, lingua franca (Smith; Crystal; Jenkins respectively) etc, which are being increasingly researched.

In this paper, nonetheless, we primarily focus our attention on an affective variable (students' attitudes) and social (the classroom seen as a community of practice), but also cultural to a certain extent (students' integration into their community of practice may well be conditioned by how relaxed they feel in it, how they assess it in terms of the quality of interaction, rapport etc). Furthermore, we view context as the most immediate learning and instructional environment, which subsumes the physical environment (e.g. textbooks, class materials) as well as psychological (e.g. students' attitudes to their teacher, their perception 
of class rapport etc). As for attitudes, they have been regarded as a good measure to predict linguistic behaviour in sociolinguistic studies (e.g. Holmes; Llamas and Watt), which is the reason why we set out to investigate them herein. ${ }^{8}$ Finally, we also include the learners' learning background (e.g. age of the first formal exposure to English) as well as one instance of input (use of L2 as the language of instruction) that can influence learners' mastery of language, their attitudes to learning the $\mathrm{L} 2$, and may bring about using the language as a tool to acquire different subject matter content outside language learning, as some studies suggest (cf. Grubor, 2020a).

Therefore, the main aims of the current research are to determine how students' belonging to different educational profiles (with English as their major or not) and different age groups (secondary and tertiary students) evaluate their most immediate learning environment. To put it differently, we wish to: (1) explore their attitudes to the English learning context; (2) determine whether their evaluation is connected with the extent to which they are exposed to the samples of language provided in the L2 through the language of instruction; and, (3) test whether the age when they started learning English plays a role in the formation of attitudes.

\section{Methodology}

\subsection{The sample}

The sample recruited for the study included 223 participants, aged 16 to $24(M=18.69, S t d=2.00)$, of both sexes $(m=67, f=156)$, two broad age groups: secondary $(\mathrm{N}=113)$ and tertiary students $(\mathrm{N}=110)$, two educational profiles: (1) 'philologically-oriented' participants (those whose major was the English language) and (2) 'non-philologicallyoriented' participants (those whose major was not related to language learning). The distribution of the said age groups within the two educational profiles was as follows: (1) philologically-oriented secondary school students (Phil), i.e. (1a) philological course students at intermediate language level $(N=56 ; m=8, f=48),(1 b)$ English language university students at proficiency level $(\mathrm{N}=50 ; \mathrm{m}=13, \mathrm{f}=37)$, and (2) nonphilologically-oriented (NonPhil), i.e. (2a) general course students at pre-intermediate language level $(\mathrm{N}=57 ; \mathrm{m}=30, \mathrm{f}=27)$, and $(2 \mathrm{~b})$ students of economics at upper-intermediate level $(N=60 ; m=16 ; f=44)$.

\footnotetext{
${ }^{8}$ More on attitudes, their structure, measurements, complexity and functions, cf. Llamas and Watt within purely sociolinguistic research, and Grubor (2015, 2020b), within SLA research.
} 
All the participants were in year 2 and 3 , since students attending year 1 or 4 may well be at an in-between age, hence not fully representing their respective age groups. The inclusion of Phil and NonPhil groups is supported by the idea that these two categories most likely have different levels of motivation to learn English, the former voluntarily having chosen to learn it and the latter having English as one of many subjects/courses. All the participants took part in the research voluntarily and provided informed consent.

\subsection{Instruments and procedures}

The following research instruments have been administered to collect data: (1) sociodemographic questionnaire, (2) English learning background questionnaire, (3) L2 learning context scale. The main purpose behind these instruments was to determine: (1) the basic sociodemographic information on the participants (age, sex, educational profile, place of birth etc), (2) the participants' L2 learning background (age when they started learning English, information on learning English inside/outside school etc), (3) their attitudes to L2 learning context $/ A L_{2} L C$ scale. The $A L_{2} L C$ scale, which may well be termed Attitudes to the Instructional Context, is a seven-point semantic differential rating scale, whereby the value 1 denotes the negative point (a 'negative' adjective, such as 'boring'), 7 the positive end (a 'positive' adjective, such as 'interesting'), while the in-between values represent gradual nuances between the extreme poles. The scale includes 10 items, reflecting different aspects of L2 learning context: their teacher/language instructors (e.g. IT4: My English teacher is passive ... active), teaching materials/textbooks (e.g. IT2: The textbook we use in English lessons is boring ... interesting), English lessons (e.g. IT1: My English lessons are static ... dynamic), classroom ambience/rapport (e.g. IT9: English classroom interaction is bad ... good). Moreover, the participants were asked to give their estimates concerning the extent to which English is used in their classes as the language of instruction ( $\left.\mathrm{L}_{2} \mathrm{Lol}\right)$. Data were analysed in IBM SPSS 21, and the following statistical procedures were employed: descriptive statistics, scale reliability test, independent samples $t$-test, one-way analysis of variance (ANOVA), Tukey's post hoc test, KMO Test for Sampling Adequacy and Bartlett's Test of Sphericity, exploratory factor analysis, and effect size was computed for every detected significant difference. 


\section{Results}

\subsection{L2 learning background}

With regard to the age when the sample started learning English, the results show a similar age (cf. Table 1). Descriptive statistics (cross tabs) indicate the age range from 3 to 14, with the majority of the participants being 11 (53.20\%) and 9 years old (25.10\%), whereas the percentage of other ages was negligible (ranging from $0.5 \%$ to $5.5 \%$ ). The vast majority of the participants also started learning English in schools at a similar age, in the $5^{\text {th }}(70.80 \%)$, and $3^{\text {rd }}$ grade $(22.40 \%)$. Although this result speaks in favour of a uniform sample in terms of the starting age, it places a limit at the same time.

\begin{tabular}{|c|c|c|c|c|c|c|c|c|}
\hline $\begin{array}{l}\text { L2 learning } \\
\text { background } \\
\left(\mathrm{L}_{2} \mathrm{LB}\right) \text { : age }\end{array}$ & \multicolumn{2}{|c|}{ at age 9} & \multicolumn{2}{|c|}{ at age 11} & \multicolumn{2}{|c|}{ from $3^{\text {rd }}$ grade } & \multicolumn{2}{|c|}{ from $5^{\text {th }}$ grade } \\
\hline $\begin{array}{l}\text { Philological } \\
\text { course (PC) }\end{array}$ & 32.10 & 32.70 & 44.60 & 20.30 & 28.60 & 32.70 & 64.30 & 23.20 \\
\hline $\begin{array}{l}\text { General course } \\
\text { (GC) }\end{array}$ & 15.10 & 14.50 & 60.40 & 26.00 & 11.30 & 12.20 & 77.40 & 26.50 \\
\hline $\begin{array}{l}\text { Faculty of } \\
\text { Philology (FP) }\end{array}$ & 34.00 & 30.90 & 58.00 & 23.60 & 28.00 & 28.60 & 68.00 & 21.90 \\
\hline $\begin{array}{l}\text { Faculty of } \\
\text { Economics (FE) }\end{array}$ & 20.00 & 21.80 & 61.70 & 31.10 & 21.70 & 26.50 & 73.30 & 28.40 \\
\hline Total & & & & & & & & \\
\hline
\end{tabular}

Table 1 L2 learning background (age)

When it comes to learning English outside the school, the majority of the participants (67.10\%) stated that they had not learnt English outside the formal framework. The remaining $32.90 \%$ additionally learnt English as follows: $67.10 \%$ out of the stated percentage attended language courses, and $32.90 \%$ private lessons. Interestingly, no other form of language learning was reported, such as staying in an English speaking country or other. As regards the formal education and their English lessons, $25.60 \%$ of the sample (GC) had two classes of English per week (approximately 72 annually), 25.10\% (PC) 5 classes weekly (around 170 a year), 49.30\% 6 classes a week (180 per year for FP and 90 for FE). ${ }^{9}$

\subsection{L2 learning context}

The employed $A L_{2} L C$ scale was designed to test the participants' evaluation of the most immediate facet of the $\mathrm{L} 2$ learning environment

\footnotetext{
${ }^{9}$ Students of the FP had English in both terms (autumn and spring), and students of FE only in one.
} 
in the educational context (their instructors, class/teaching materials, lessons, rapport etc). The scale reliability test showed very good internal consistency $\alpha=.897$, which gave rise to further analyses.

Descriptive statistics indicate that the total mean value of the scale is not very high, but the values vary according to the groups of the sample (cf. Table 2).

\begin{tabular}{l|cccccc} 
L2 learning context $\left(\mathbf{L}_{2} \mathbf{L} \mathbf{C}\right)$ & $\mathbf{N}$ & $\mathbf{M}$ & SD & SE & Min & Max \\
\hline Philological course (PC) & 56 & 57.80 & 11.80 & 1.58 & 26 & 70 \\
General course (GC) & 57 & 53.67 & 8.99 & 1.91 & 26 & 66 \\
Faculty of Philology (FP) & 50 & 52.44 & 9.17 & 1.30 & 23 & 67 \\
Faculty of Economics (FE) & 60 & 46.23 & 9.98 & 1.29 & 27 & 65 \\
Total (max. 70) & $\mathbf{2 2 3}$ & $\mathbf{5 2 . 4 3}$ & $\mathbf{1 0 . 8 9}$ & $\mathbf{0 . 7 4}$ & $\mathbf{2 3}$ & $\mathbf{7 0}$ \\
\hline
\end{tabular}

Table 2 L2 learning context (descriptive statistics)

Since the scale assumes the existence of some key components of the learning context, as the factors or subfactors comprising the said construct, we set out to determine its structure. Prior to conducting exploratory factor analysis (EFA), we employed KMO and Bartlett's tests, whose results confirmed that the items on the scale could be factorised (KMO $=.905 ; \chi^{2}(45)=1159.843, p=.000$ ).

The intercorrelation matrix was computed from the evaluated attitudes, and afterwards factor analysed. By means of EFA only one factor was extracted, explaining $54.54 \%$ of the total variance observed, including all the items on the $A L_{2} L C$ scale (cf. Table 3). The $L 2$ learning context thus has shown to be one composite construct in our sample, including different facets (teacher, method of teaching, teaching materials, class rapport etc).

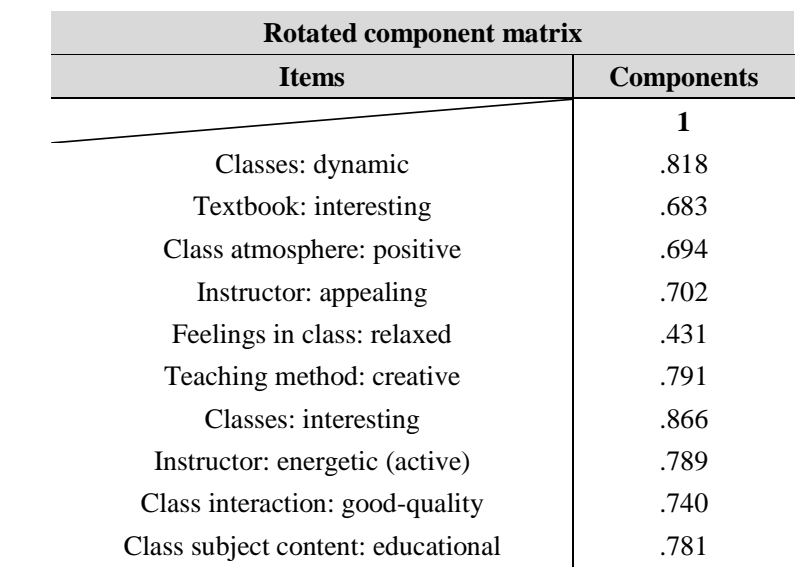

Method: Principal Component Analysis (Varimax Rotation with Kaiser Normalisation)

a. Extracted 1 component

Table 3 Factor Loadings $>.60$ 
In view of establishing whether the participants' evaluation of their L2 learning context differs between groups, we employed ANOVA, which showed a statistically very significant difference with large effect size $\left(F(3,215)=13.195 ; p=.000 ; \eta^{2}=.18\right)$. In order to check whether the difference lies in age, we performed $t$-test, which revealed that the secondary students evaluated their $L 2$ learning context much better than tertiary $\left(t(217)=4.847 ; p=.000 ; \eta^{2}=.10\right)$. Finally, by the age criterion, a borderline difference with small-to-moderate effect size was found in subgroups of secondary $\left(t(107)=2.016 ; p=.046 ; \eta^{2}=.04\right)$, but very significant difference, and with moderate-to-large effect size in tertiary students $\left(t(108)=3.368 ; p=.001 ; \eta^{2}=.09\right) .{ }^{10}$

To conclude, the differences were found in the participants who had chosen to learn the language and those who had English just as one out of many subjects/courses. Nevertheless, the difference is very big in tertiary students, which may imply either that the L2 learning context is more important to English language and literature students than students of economics, or that the L2 learning context is simply better in the former setting.

Despite the fact that one single factor was extracted via EFA, we will present the results of the assumed components, i.e. facets of the context of L2 learning. The distribution of the participants' evaluation of each individual component, within the education profile groups, is presented in Table 4.

The mean score of the participants' evaluation of their English lessons (how dynamic/interesting/educational they are) is moderate. With the aim of checking whether there is a significant difference between the age groups, we administered $t$-test. The test showed a significant difference, but of small-to-moderate effect size between secondary and tertiary students $\left(t(217)=2.813 ; p=.005 ; \eta^{2}=.03\right)$. When employed within each age group, it showed a significant difference of moderate-to-large effect size between Phil and NonPhil in tertiary students $\left(t(108)=3.318 ; p=.001 ; \eta^{2}=.09\right)$, but not secondary.

\begin{tabular}{l|cccccc} 
English lessons & $\mathbf{N}$ & $\mathbf{M}$ & SD & SE & Min & Max \\
\hline Philological course & 56 & 16.32 & 4.62 & 0.63 & 5 & 21 \\
General course & 57 & 16.00 & 3.08 & 0.42 & 8 & 20 \\
Faculty of Philology & 50 & 15.90 & 3.15 & 0.45 & 7 & 21 \\
Faculty of Economics & 60 & 13.82 & 3.38 & 0.44 & 6 & 20 \\
Total (max. 21) & $\mathbf{2 2 3}$ & $\mathbf{1 5 . 4 6}$ & $\mathbf{3 . 7 4}$ & $\mathbf{0 . 2 5}$ & $\mathbf{5}$ & $\mathbf{2 1}$ \\
\hline Instructional materials & $\mathbf{N}$ & $\mathbf{M}$ & SD & SE & Min & Max \\
\hline
\end{tabular}

\footnotetext{
${ }^{10}$ Tukey's post hoc test employed on Phil and NonPhil groups supported these results: significant differences in favour of Phil groups, in secondary ( $M D=5.364$; $S E=1.96 ; p=0.034)$, in tertiary students $(M D=6.207 ; S E=1.93 ; p=0.008)$.
} 


\begin{tabular}{l|cccccc} 
Philological course & 56 & 5.77 & 1.17 & 0.16 & 3 & 7 \\
\hline General course & 57 & 5.08 & 1.48 & 0.20 & 1 & 7 \\
\hline Faculty of Philology & 50 & 4.62 & 1.43 & 0.20 & 1 & 7 \\
\hline Faculty of Economics & 60 & 3.13 & 1.58 & 0.20 & 1 & 7 \\
\hline Total (max. 7) & $\mathbf{2 2 3}$ & $\mathbf{4 . 6 2}$ & $\mathbf{1 . 7 3}$ & $\mathbf{0 . 1 2}$ & $\mathbf{1}$ & $\mathbf{7}$ \\
\hline Class ambience & $\mathbf{N}$ & $\mathbf{M}$ & $\mathbf{S D}$ & $\mathbf{S E}$ & Min & Max \\
\hline Philological course & 56 & 6.02 & 1.38 & 0.18 & 1 & 7 \\
\hline General course & 57 & 5.15 & 1.50 & 0.21 & 1 & 7 \\
\hline Faculty of Philology & 50 & 5.64 & 1.26 & 0.18 & 3 & 7 \\
\hline Faculty of Economics & 60 & 5.05 & 1.33 & 0.17 & 2 & 7 \\
\hline Total (max. 21) & $\mathbf{2 2 3}$ & $\mathbf{5 . 4 6}$ & $\mathbf{1 . 4 2}$ & $\mathbf{0 . 1 0}$ & $\mathbf{1}$ & $\mathbf{7}$ \\
\hline English instructor/teaching & $\mathbf{N}$ & $\mathbf{M}$ & $\mathbf{S D}$ & $\mathbf{S E}$ & $\mathbf{M i n}$ & $\mathbf{M a x}$ \\
\hline Philological course & 56 & 17.75 & 4.33 & 0.58 & 3 & 21 \\
\hline General course & 57 & 17.40 & 2.67 & 0.37 & 12 & 21 \\
\hline Faculty of Philology & 50 & 15.70 & 3.29 & 0.46 & 4 & 21 \\
\hline Faculty of Economics & 60 & 15.02 & 3.74 & 0.48 & 7 & 21 \\
\hline Total (max. 21) & $\mathbf{2 2 3}$ & $\mathbf{1 6 . 4 5}$ & $\mathbf{3 . 7 4}$ & $\mathbf{0 . 2 5}$ & $\mathbf{3}$ & $\mathbf{2 1}$ \\
\hline
\end{tabular}

Table 4 Descriptive statistics: evaluation of individual components on the

$\mathrm{AL}_{2} \mathrm{LC}$ scale

\subsection{Language of instruction}

The language of instruction $\left(\mathrm{L}_{2} \mathrm{LO} \mathrm{O}\right)$ variable was computed through students' estimates of how frequently the $L 2$ is used in their English classes as the language of instruction, and consequently compared to their instructor's estimate. ${ }^{11}$ The response range varies from 1 (never) to 5 (always). Within the secondary students group, there were different classes involved in each educational profile, while in the tertiary students we only gained their perceived estimates (cf. Note 5). The mean values according to the educational profiles vary from 2 (FE), 3 (FP), 3.5 (GC), to 4 (PC).

Since previous research showed the link between the $L_{2} \mathrm{Lol}$ and students' evaluation of their $\mathrm{L}_{2} \mathrm{LC}$ (Grubor, 2020a), we performed the correlation analysis. The correlation was strong and statistically significant in the entire sample $(r=.521 ; p=.000)$ and within the secondary school group $(r=.527 ; p=.000)$, and moderate within the tertiary group ( $r=.308 ; p=.001$ ), indicating that the more English is used as the Lol, the more positive evaluation of the $\mathrm{L}_{2} \mathrm{LC}$ is. Following on Larson-Hall, we checked effect size for the obtained correlations to test whether they might have been influenced by the sample size. The results show large effect size is in the entire sample $\left(R^{2}=.27\right)$ and within secondary students $\left(R^{2}=.28\right)$, and moderate in tertiary students $\left(R^{2}=.09\right)$, thereby confirming the results of the correlation analysis. As initially assumed, the $\mathrm{L}_{2} \mathrm{Lol}$ and $\mathrm{L}_{2} \mathrm{LC}$ variables are connected, and apparently

\footnotetext{
${ }^{11}$ This controlled effect was conducted only in secondary school students since they only had one English teacher, whereas it was impossible to ask all the language instructors to what extent they use English in tertiary Phil students.
} 
students who are more frequently exposed to L2 through its use as the language of instruction, evaluate their immediate learning context better. This is particularly valid in the group of secondary students.

\section{Discussion}

As defined earlier, the $\mathrm{L}_{2} \mathrm{LC}$ is the most immediate learning environment that students come into contact with while acquiring an L2, which is theoretically comprised of the external, physical environment (e.g. class materials/equipment) and psychological, individual-specific (e.g. students' attitudes to teachers and their teaching, quality of classroom interaction etc).

With regard to the instructional conditions of $L 2$ learning (i.e. where learning takes place within the classroom settings), Loewen states that SLA takes into account the situation where students are trying to acquire an L2 through systematic manipulation of these conditions. Consequently, Butler infers that this "manipulation" can pertain to "the process in which the learners engage with the input", in addition to the manipulation of the linguistic input itself (322). However, we would like to further elaborate on this hypothesis by adding psychologically-oriented situations, along with Butler's dimension of learners' attitudes to learning and teaching, in which students come into contact with the L2 input in the sense that the learning environment arouses feelings, encourages beliefs and reinforces attitudes in relation to the target language and learning the L2. In a similar vein, Gardner (1985) argues that the teacher and teaching methods can have a great impact on students' attitude formation (within his socioeducational model in SLA, particularly relative to the study of motivation). Gardner and his associates determined the variable attitudes towards the learning situation to be significant for $\mathrm{L} 2$ motivation, and to influence students' L2 grades indirectly.

Accordingly, the first aim that we set in this study was to determine the participants' attitudes to their $\mathrm{L}_{2} \mathrm{LC}$. In terms of psychometric properties of the administered scale, it displayed good internal consistency and reliability, which means that it measures the contents it intended to measure. Overall, our sample evaluated their $\mathrm{L}_{2} \mathrm{LC}$ moderately, with varying values across the subgroups. Secondary students evaluated their $\mathrm{L}_{2} \mathrm{LC}$ better, but effect size was small. This result may be interpreted in the light of different educational settings in secondary and tertiary education, especially with respect to Phil tertiary students, who were tasked to give an overall estimate of their English classes, while secondary students could focus only on one teacher. 
However, Phil tertiary students evaluated their $L_{2} L C$ significantly better, as did Phil secondary students. One factor was extracted via EFA, which suggests that the assumed components constitute the construct of $L_{2} L C$, at least for our sample. Despite this finding, we tested their attitudes towards specific components of the assumed construct so as to analyse their attitudes in more detail. Concerning their English lessons and instructional materials, generally speaking, secondary students and Phil groups within the age groups reported higher estimates. This finding may be closely connected to different educational settings in secondary and tertiary education as stated above, but also may be indicative of the fact that this variable $\left(L_{2} L C\right)$ might play a more important role in secondary students. Furthermore, more positive evaluation reported by Phil groups speaks in favour of the individual's voluntary choice to study the L2, which is expected. Regarding class ambience, and English instructor and their teaching methods, a significant difference was found according to the educational profiles in the first instance, and according to age in the second. Class ambience, or the way students feel in English classes, is more positively evaluated in those groups who voluntarily chose to study the $L 2$, which can be a signal of the level of motivation to learn the $L 2$, but it can also mean that they feel better because they are studying something they have an affinity for and are good at. As for English instructor and their teaching methods, the fact that secondary students reported higher values may be interpreted differently. First, these two dimensions may simply be more significant for secondary students than tertiary, who may conceive of their educational environment as being placed at a "higher, academic level", where the rapport and interaction between the instructor and learners are not as immediate as in schools. Next, the problem with Phil tertiary students remains the same with regard to having to provide an overall estimate, in which case the values may greatly vary from instructor to instructor.

Our second aim was to determine whether the participants' attitudes to $L_{2} L C$ are connected with the extent to which English is used as the Lol. With this respect, we hypothesised that students having $L_{2}$ Lol might form more positive attitudes to their $\mathrm{L}_{2} \mathrm{LC}$ since they get hands-on experience with the $L 2$. On the one hand, the frequency of using the $L 2$ provides the learners with plenty of opportunities for further practice, thereby increasing their self-confidence. On the other hand, learners are becoming closer to the target language culture (whether actual or perceived/imagined) and thus develop their pragmatic (cf. Carter) as well as other competences (cf. Celce-Murcia). What is more, the results of many studies support the idea that having $L_{2}$ Lol facilitates the $L 2$ 
acquisition, directly or indirectly (e.g. Gradman and Hanania; Marsh, $\mathrm{Hau}$, and Kong; Taguchi), and definitely promotes more positive attitudes to the $\mathrm{L}_{2} \mathrm{LC}$ as well as learning the L2 (e.g. Grubor, 2020a; Yashima and Zenuk-Nishida). In a nutshell, the results of our study further corroborate this idea, suggesting that the more frequent the use of English as the Lol, the more positive attitudes to the $L_{2} L C$ are.

Finally, our last aim was to determine whether the starting age of formal instruction in English might have had an impact on the participants' attitudes, and the results showed no significant correlations. However, this connection should not be discarded completely, since the composition of our sample prevented analyses in the sense that the vast majority of the participants started learning English at the approximately same age, which is one of the limitations of the study.

In addition to this, there are other limitations that we would like to point to. Firstly, the main differences were reported between Phil and NonPhil groups, and Phil groups are typically comprised of female participants, as was the case in our study. This fact prevented us from making comparisons by the sex criterion, which we did not perform due to the stated. Secondly, a bigger number of different classes in the context of secondary would be desirable, as well as including more faculties in the case of tertiary students.

\section{L2 learning context: Further ahead}

The L2 learning/instructional context, in our opinion, constitutes an integral part of the learning environment in formal settings. This factor was hypothesised to subsume the teacher and the quality of their teaching (i.e. teaching methods), teaching materials, classroom interaction, class ambience. According to the sample of the present study, this is one (composite) factor. The differences reported by the participants may well be an indication of different educational formats (secondary v. tertiary students), or simply learning an L2 at an academic level does not provide as many stimuli, as secondary school classrooms do. Such a claim would however be overly simplified. What is more plausible is that the subsumed components are simply more important for young adolescents. Alternatively, tertiary students may simply have greater expectations, especially Phil students, and NonPhil students might not find the environment in which they learn English relevant at all, since they might need it for practical purposes only (either to pass the course or to master the $L 2$ due to their future job requirements).

Having $L_{2}$ Lol, in our view, plays a crucial role in better mastery of the $L 2$, in the development of pragmatic competence and spontaneous 
language use, on a linguistic plane, but also in creating a target language community, comprising of members who use the same target language in their communications for a wide array of purposes (e.g. informal conversation, group decision-making, task completion, acquiring subject content matters outside L2 learning etc), on a more social and psychological plane. Many authors emphasise the need to maximise learners' exposure to $L 2$ input, especially of good-quality, which may be provided naturally in this way. A study conducted round the world, including 55 countries (both private and state sectors, schools and universities) found that using English as a medium of instruction, in this very instance, is more prevalent in the private sector, but there is a growing need to increase its use due to the internationalisation and mobility (cf. Dearden). Although this study aims at bilingual or else education delivered through English, we believe that L2 teachers may make a valuable contribution to the development of learners' sociopragmatic competences, at the same time potentially preparing their students, and stakeholders to that matter, for a change connected with the said internationalisation and mobility.

Moreover, we explored young and older adolescents' attitudes to their most immediate learning environment, through a disguised structured technique, the semantic differential, which is a good and reliable measure of attitudes (Wang). Among many functions that they have, attitudes serve a social identity function, in helping people define themselves and their place in groups, and the impression management function, in enabling them to connect with their environment (Smith, Mackie, and Claypool). ${ }^{12}$ The L2 learning context in this sense may be taken as an instance of a specific community of practice, as seen in sociolinguistic research, which learners aspire to connect with and be part of, i.e. which they want to integrate into. On the other hand, it may also have an important role in the development of L2 identity, whereby all agents of the L2 learning context (immediate: teacher, peers, their own individuality, distant: other target language speakers) constitute an individual's target language community since identity is regarded as "socioculturally constructed" (Norton 318), with the emphasis on the individual's agency and the role of language and discourse practices in the construction of identity (Block; Norton and McKinney). ${ }^{13}$

If we adopt the standpoint that attitudes make an impact on the performance of linguistic behaviour, we propose that the L2 learning

\footnotetext{
12 For an insightful analysis, cf. Grubor (forthcoming).

${ }^{13}$ The issue of $L 2$ identity and the importance of $L 2$ culture will be discussed and explored in-depth elsewhere.
} 
context should be further investigated with respect to their potential influence on attitudes towards specific behaviours (i.e. learning English), and consequently L2 linguistic behaviour. Furthermore, it would be useful to include other sources of input in the analysis in order to determine the constituent parts of the broader concept of L2 learning environment, which has been assumed to be crucial for the process of SLA for many years. Finally, this study has provided us with some useful information on the importance of using English as the language of instruction for the formation of positive attitudes, which may be directly applicable to ELT practitioners and their everyday teaching.

\section{Works Cited:}

Block, David. Second Language Identities. London: Continuum International, 2010.

Butler, Yuko Goto. "ISLA in East Asian Contexts". The Routledge Handbook of Instructed Second Language Acquisition. Ed. Shawn Loewen and Masatoshi Sato. New York: Taylor \& Francis, 2017, 321-337.

Carter, Ronald. "Key concepts in ELT: Language awareness". ELT Journal 57.1 (2003): 64-65.

Celce-Murcia, Marianne. "Rethinking the role of communicative competence". Intercultural Language Use and Language Learning. Ed. Eva Alcón Soler, Safont Jordà and Maria Pilar. Dordrecht: Springer, 2007. 41-57.

Crystal, David. English as a global language. $2^{\text {nd }}$ ed. Cambridge: Cambridge U P, 2003.

Dearden, Julie. English as a medium of instruction: A growing global phenomenon. London: British Council, 2014.

De Costa, Peter, and Dustin Crowther. "Second Language Acquisition and World Englishes: Dialogue and Engagement". World Englishes 37.2 (2018): 19-33.

Dörnyei, Zoltan. "Motivation and Motivating in the Foreign Language Classroom". The Modern Language Journal 78.3 (1994): 273-284.

Duff, Patricia. "Social dimensions and differences in instructed SLA". The Routledge Handbook of Instructed Second Language Acquisition. Ed. Shawn Loewen and Masatoshi Sato. New York: Taylor \& Francis, 2017. 379-395.

Dulay, Heidi, Marina Burt, and Stephen Krashen. Language Two. New York: Oxford U P, 1982.

Ellis, Rod. Instructed Second Language Acquisition. Oxford: Basil Blackwell, 1990.

Ellis, Rod. Understanding Second Language Acquisition. Oxford: Oxford U P, 1985.

Gardner, Robert. "Motivation and Second Language Acquisition". Porta Linguarum 8 (2007): 9-20.

Gardner, Robert. Social Psychology and Second Language Learning: The Role of Attitudes and Motivation. London: Edward Arnold, 1985. 
Gass, Susan. Input, Interaction, and the Second Language Learner. Mahwah: Lawrence Elrbaum, 1997.

Gass, Susan, and Larry Selinker. Second Language Acquisition: An Introductory Course. $3^{\text {rd }}$ ed. New York: Routledge, 2008.

Gradman, Harry, and Edith Hanania. "Language Learning Background Factors and ESL Proficiency". The Modern Language Journal 75.1 (1991): 39-51.

Grubor, Jelena. "Beyond Teaching English: EFL Students' Accounts of Learning Outcomes in a Cooperative Class". Naučne publikacije Državnog univerziteta u Novom Pazaru: Društvene \& humanističke nauke 3.2 (2020a): 80-95.

Grubor, Jelena. "What Makes up the Attitude to Learning English: EFLS-ALE Scale". Science Beyond Boundaries 3. Ed. Mirjana Lončar-Vujnović et al. U of Priština, 2020b, in press.

Grubor, Jelena. "Vannastavni input i stav prema učenju engleskog kao stranog jezika". Primenjena lingvistika 19 (2018): 61-74.

Grubor, Jelena. "Ispitivanje L2 stavova". Inovacije u nastavi 28.1 (2015): 140148.

Holmes, Janet. An introduction to Sociolinguistics. $4^{\text {th }}$ ed. Oxon: Routledge, 2013.

Jenkins, Jennifer. English as a Lingua Franca: Attitude and Identity. Oxford: Oxford U P, 2007.

Krashen, Stephen. Principles and Practice in Second Language Acquisition. New York: Pergamon P, 1982.

Larson-Hall, Jenifer. A Guide to Doing Statistics in Second Language Research Using SPSS. New York: Routledge, 2010.

Littlewood, William. "Communicative and task-based language teaching in East Asian classrooms". Language Teaching 40 (2007): 243-249.

Llamas, Carmen, and Dominic Watt. "Scottish, English, British?: Innovations in Attitude Measurement". Language and Linguistics Compass 8.11 (2014): 610-617.

Loewen, Shawn. Introduction to Instructed Second Language Acquisition. New York: Routledge, 2015.

Marsh, Herbert, Kit-Tai Hau, and Chit-Kwong Kong. "Multilevel causal ordering of academic-self concept and achievement: Influence of language of instruction (English compared with Chinese) for Hong Kong students". American Educational Research Journal 39.3 (2002): 727-763.

McLaughlin, Barry. Theories of Second Language Learning. London: Edward Arnold, 1987.

Miličević Petrović, Maja, and Jelena Grubor. "Input i postignuće u usvajanju stranog jezika“. Anali filološkog fakulteta 31.1 (2019): 183-212.

Mitchell, Rosamond, Florence Myles, and Emma Marsden. Second Language Learning Theories. $4^{\text {th }}$ edn. Oxon: Routledge, 2019.

Norton, Bonny. Identity and Language Learning. Extending the Conversation. $2^{\text {nd }}$ ed. Bristol: Multilingual Matters, 2013. 
Norton, Bonny, and Carolyn McKinney. "An Identity Approach to Second Language Acquisition". Alternative Approaches to Second Language Acquisition. Ed. Dwight Atkinson. Abingdon: Routledge, 2011. 73-94.

Richards, Jack, and Richard Schmidt. Longman Dictionary of Language Teaching and Applied Linguistics. $4^{\text {th }}$ ed. Harlow: Pearson E, 2010.

Saville-Troike, Muriel. Introducing Second Language Acquisition. $2^{\text {nd }}$ ed. Cambridge: Cambridge U P, 2012.

Smith, Larry. Readings in English as an International Language. Oxford: Pergamon P, 1983.

Smith, Eliot, Diane Mackie, and Heather Claypool. Social psychology. $4^{\text {th }}$ ed. New York: Psychology P, 2015.

Taguchi, Naoko. "The Role of Learning Environment in the Development of Pragmatic Comprehension: A Comparison of Gains Between EFL and ESL Learners". Studies in Second Language Acquisition 30 (2008): 423-452.

VanPatten, Bill, and Alessandro Benati. Key Terms in Second Language Acquisition. $2^{\text {nd }}$ ed. London: Bloomsbury A, 2015.

Wang, Xuan. "Investigating the Role of Speaker Attitudes in Koinéisation in Hohhot, China". Asia-Pacific Language Variation 3 (2017): 232-270.

Yashima, Tomoko, and Lori Zenuk-Nishida. "The Impact of Learning Contexts on Proficiency, Attitudes and L2 Communication: Creating an Imagined International Community". System 36.4 (2008): 566-585.

Zappa-Hollman, Sandra, and Patricia Duff. "Academic English Socialization Through Individual Networks of Practice". TESOL Quarterly 49.2 (2015): 333-368.

\section{KONTEKST UČENJA ENGLESKOG KAO STRANOG JEZIKA (S-KUL 2 SKALA)}

Najneposrednije nastavno okruženje za učenike drugog/stranog jezika (L2) jeste kontekst učenja L2 (KUL2), koje samim tim potencijalno utiče na stavove prema L2 ali i na jezičko ponašanje. $U$ ovom radu, prvenstveno smo se fokusirali na afektivnu varijablu (tj. stavove učenika), i društvenu ( $\mathrm{tj}$. učionicu kao delatnu zajednicu/DZ), ali indirektno i kulturnu (integraciju učenika u DZ). Glavni cilj istraživanja je da se ispitaju stavovi dve starosne grupe koje pripadaju dvama obrazovnim profilima prema $\mathrm{KUL}_{2}$, a pomoćni da se utvrdi da li je procena $K U L_{2}$ povezana sa jedne strane sa stepenom izloženosti učenika L2 kroz njegovu upotrebu kao jezika učionice ( $\left.\mathrm{L}_{2} \mathrm{JU}\right)$, a sa druge starosnom dobi kada su ispitanici počeli da uče L2. Glavni primenjeni instrument je skala S-KUL2, koja je pokazala dobre psihometrijske karakteristike, a prikupljeni kvantitativni podaci analizirani su u statističkom programu IBM SPSS 21. Ukratko, rezultati pokazuju da je KUL2 složeni faktor, usko povezan sa frekventnošću upotrebe $L_{2} J U$, što opravdava upotrebu L2 u nastavi jezika. Srednjoškolci su svoj KUL2 procenili bolje od studenata, a značajne razlike pronađene su kod pojedinačnih komponenti između starosnih grupa i obrazovnih profila unutar navedenih grupa. Da zaključimo, dalja istraživanja su neophodna kako bi se $\mathrm{KUL}_{2}$ ispitao 
podrobnije, kao i njegova uloga unutar šireg konteksta jezičkog okruženja, koji uključuje i druge izvore inputa kojima su učenici izloženi, i njihov odnos sa stavovima prema učenju L2, i potencijalno postignućem.

Ključne reči: delatne zajednice, kontekst učenja $L 2\left(K L_{2}\right)$, L2 kao jezik učionice $\left(\mathrm{L}_{2} \mathrm{JU}\right)$, skala stavova prema kontekstu učenja L2 (S-KUL2), stavovi prema L2. 